\title{
THE TIME FOR THE NEXT STEPS IS HERE - FROM CLASSIC TO MODERN PARADIGMS IN MOTIVATION
}

\author{
Monika Icheva ${ }^{1}$ and Valentin Vasilev ${ }^{2}$ \\ ${ }^{1} \mathrm{PhD}$ Student, Faculty of Law and History, South-West University “Neofit Rilski”, Blagoevgrad, \\ Bulgaria \\ ${ }^{2}$ Assoc. Prof. Valentin Vasilev, Faculty of Law and History, Ph.D.South-West University "Neofit \\ Rilski”, Blagoevgrad, Bulgaria \\ DOI: 10.46609/IJSSER.2021.v06i03.012 URL: https://doi.org/10.46609/IJSSER.2021.v06i03.012
}

\begin{abstract}
The dynamics of relations in organizations at the moment are like in a "pressure cooker". The constant changes, the pandemic pressure for new decisions and the unreinforced decision-making processes in such a volatile environment, have led to the formation of a radically different and unknown to practice and theory challenge to human resource management. In today's complex and changing environment, associated with constant changes in legislation, inflation, rising unemployment and the economy, global pandemics and crises, the challenge of finding new motivational messages and tools in everyday work is a daily task for management and is increasingly the biggest challenge for organizations in a holistic context.
\end{abstract}

Keywords: motivation; crisis; change; innovation; new solutions

\section{Introduction}

Motivation is the main driving force that "leads" us forward and helps us realize our personal goals and dreams. In the context of management theory, motivation is a basic management function and is a process of making a voluntary decision for a certain purposeful action or inaction in a certain situation. It has a subjective nature and is determined by the economic, organizational and social environment in the organization.(Vasilev \& Georgiev, 2018)

In today's complex and changing environment, associated with constant changes in legislation, inflation, rising unemployment and the economy, global pandemics and crises, the challenge of selecting qualified and capable employees is proving to be an increasing challenge for organizations. The main impulse caused by globalization is expressed by the recognition of the fact that improvements in organizational performance are closely related to the human factor, 
International Journal of Social Science and Economic Research

ISSN: 2455-8834

Volume:06, Issue:03 "March 2021"

and hence practices in recruitment, selection, working methods, relationships with staff, motivation policy and all other aspects related to organizational behavior.( Kresnaliyska \& Chorbadzhiyska, 2017)

\section{New realities in organizational development and motivation}

The new realities undoubtedly require the human factor in the organization to be given paramount importance, focused on the individual on the one hand, and on teamwork on the other. Building relationships that are based on values such as honesty, fairness and trust is an element of the new management culture of organizations.

Trust plays a key role in sharing values and in achieving commitment to the organization.(Vasilev \& Dimitrova, 2017) On the other hand, leadership behavior develops leadership style and skills. Leadership skills are based on leadership behavior. Leadership behavior is related to motivation - both individual and the whole organization. (Vasilev \& Efremovski, 2014)

The effective management of human resources is based on the use of modern methods, tools and instruments from the world and local practice in this field. Such management requires managers who have high morals, values and patterns of behavior, consistent with the stated values of the organization, who understand the significant effect of improving management and who work to improve the human resources system to achieve better results. . In this regard, we are increasingly looking for different and personalized motivational practices that are influential. Communications play an important role here. Motivational communication is any communication that aims to stimulate the commitment of employees to be involved in the realization of organizational goals. The principle of motivational communication aims at motivation to arise naturally as a result of changed perceptions of employees in life and professional situations. (Vasilev, Stefanova \& Angelova, 2017)

The use of feedback, which is a matter of good organization and an approach to its implementation, can also have a strong motivating effect. (Vasilev, Stefanova \& Angelova, 2017)

In addition, the basis for job satisfaction and motivation can be different physical and social conditions in which a person works, organizes, achieves results and has the opportunity to develop. (Vasilev \& Efremovski, 2017)

It is these examples that show that, as part of motivational policy, not only material factors but also intangible incentives are beginning to be present to ensure recognition, commitment and 


\section{International Journal of Social Science and Economic Research}

ISSN: $2455-8834$

Volume:06, Issue:03 "March 2021"

work-life balance. More and more attention is being paid to the social role of the individual, his personal values, morals and qualities. This is achieved thanks to the social responsibility that every organization begins to exercise. (Vasilev \& Icheva, 2020)

The challenges of motivation, commitment and the use of technology to deliver effective public services continue to face the public sphere, despite significant changes and improvements, especially in the area of human resource management. "HRM plays a central role in these circumstances related to employee health and organizational change. Human resource managers are seen as a bridge between management and staff to communicate with them, to positively uphold organizational values." (Gigauri, 2020)

The main document aimed at modernizing the overall appearance of the state administration in Bulgaria is the Strategy for Development of the State Administration - 2014-2020. (Strategy for Development of the State Administration - 2014-2020) It is through it that efforts have been made to increase the motivation of employees, improve their skills and provide quality services to citizens. This can be made possible by improving technology and multiplying good practices from business to the public sphere. "Providing open data by public institutions is the 'fuel' that drives initiatives by business and civil society organizations for civic IT support. Their ideas and innovative thinking can lead to the creation of useful applications for citizens, which are not provided for in the decision to collect a specific type of information. "(Handbook for Crowd sourcing and Civic hacking)

In addition to the highly motivating impact of the improvement of information and communication technologies and their application in the public sphere, the importance of employee engagement in the context of motivational and social policy is growing. An example of this is the research that has been done by the Institute of Public Administration in recent years. (Engagement barometer) They prove that engaged employees perform better for the purposes of the organization in which they occur and feel more substantial and motivated.

To manage effectively enough and provide the necessary conditions conducive working environment and motivation of employees, supervisors and managers must possess a certain style of management and a set of qualities and skills. The literature lists some basic skills such as: (Vasilev \& Belyovska, 2018)

Technical skills - the ability to use specific and specialized knowledge, skills, techniques and resources.

Human skills - the ability to listen, understand and motivate people. These skills are important because each leader performs his tasks through subordinates and reflects their 


\section{International Journal of Social Science and Economic Research}

ISSN: $2455-8834$

Volume:06, Issue:03 "March 2021"

leadership qualities.

Conceptual skills - the ability to discover and analyze complex situations by identifying alternatives and making decisions.

Definitely, the work of leaders in the 21st century is focused on improving their skills, social qualities and policies, rather than giving constant orders and instructions in an overly conservative and commanding tone. Examples are the projects and strategies developed by public institutions, as well as the effective public policies they pursue in the field of social responsibility and human resource management.

Undoubtedly, one of the institutions that influences the appearance, goals and mission of public administration is the European Union. With the continuous normative acts and programs it provides conditions for overcoming some of the main shortcomings of the modern society unemployment, economic growth, complex bureaucratic system, etc. Here it is necessary to add the influence of information and smart technologies, which significantly change the management in each organization. (Vasilev \& Ognyanski, 2020)

Publisher Richard Stag sums it up: "Nowadays, the" big "mission and good workplace style are valued no less than the big desk and the good prospects for promotion. Who would get up early in the morning in the name of some obscure goal of the organization. If people see real meaning in their work and if they have the freedom and resources to pursue the realization of their ideas, then the place is good for them". (Nopdstom \& Ridderstrale, 1999)

\section{About good examples and practices}

A key moment of the adoption of the new paradigm of employee motivation is the search and approbation of good practices.

An example of a program that supports young scientists is Horizon 2020, in particular through the activities of the Marie Skłodowska-Curie Program, which provides funding to support crossborder, cross-sectoral and interdisciplinary mobility of researchers. Individual scholarships help young scientists to pursue part of their careers in another country inside or outside the Union. They also provide an opportunity to resume a research career after a break. (https://what-europedoes-for-me.eu/bg/portal/2/B02) Through this initiative, the European Union demonstrates its social responsibility for the development of young scientists and has a motivating impact on them.

An example of how the overall appearance of organizational behavior changes in the 


\section{International Journal of Social Science and Economic Research}

ISSN: 2455-8834

Volume:06, Issue:03 "March 2021"

implementation of its tasks and goals is also available in Bulgarian institutions. One of the initiatives, which is under the patronage of the President of the Republic of Bulgaria, is the "Bulgarian Christmas". Its mission and goals are to promote philanthropy in the country, to help solve important for society problems affecting the health of children and to support specific children in need of expensive treatment and rehabilitation.

Good practices for active social policy exist, not only at the national level, but also at the local level. An example of this is the charity initiative "Donate your childhood books", organized by the public mediator of the city of Blagoevgrad, together with the Regional Library "Dimitar Talev". The campaign aims to promote early childhood reading.

The business environment can be much more flexible in terms of its social policy, as it also has more resources. An example of this is the campaign "Let's clean Bulgaria together" of bTV Media Group, which is the largest volunteer initiative in our country and aims to build public awareness on issues related to environmental protection and to make Bulgaria cleaner and more beautiful in the long term. (https://daizchistim.bg/za-kampaniqta ) In recent years, the campaign has become a tradition involving more and more celebrities and employees from the business and the public sector.

In the context of environmental protection, we should mention another initiative in which municipalities are increasingly involved - the collection of plastic caps in order to purchase incubators for maternity wards in the country. A charity initiative that shows care for nature and the desire to help.

Volunteering as a good practice uses the largest Bulgarian private company in the field of natural gas - "Overgas Inc." Volunteering engages employees emotionally and intellectually. Companies that implement such social causes are more likely to enjoy a team that believes it can impact their environment and that is able to stand its ground and thrive. For several years in a row, the company has organized a "Volunteer Day". 354 employees of the company "enlighten" the whole country with good deeds. The company explains that volunteering is one of their causes for creating a community, counteracting alienation and indifference. They are becoming a tradition for the gas company, which over time has become a necessity for the team. The good causes also attract the families of some of the employees in the company, who also donated work, energy, time, kindness and heart. ( https://csr.bg ) This good practice helps to unite the team in the name of good and sets a great example to other organizations, but also helps to improve communication, reduce stress and prevent any conflicts that may arise in the process. And the fact that employees participate in the initiative with their families proves even more the company's social commitment. 
International Journal of Social Science and Economic Research

ISSN: 2455-8834

Volume:06, Issue:03 "March 2021"

The international company "Coca Cola", which is a leader in the sale and bottling of a wide range of soft and carbonated beverages, water, energy and alcoholic beverages. In its motivational policy, the organization motivates its people by involving them in the noble initiatives it organizes in the field of education, environmental protection and culture. In its activity "Coca Cola" organizes (https://bg.coca-colahellenic.com):

\section{- "Start Success - Coca-Cola HBC and Junior Achievement"}

This educational program was created in cooperation between Coca-Cola HBC and Junior Achievement to support youth development in Bulgaria. The program aims to reduce the number of economically inactive young people in Bulgaria through the use of educational modules, solving business cases and mentoring.

\section{- "My Green City"}

Coca-Cola Bulgaria's largest environmental initiative shows how we can all contribute to improving the environment by focusing on afforestation and forest protection.

\section{- "The Place-Active Saturday"}

Active Saturday is a national campaign aimed at motivating people to be more active in their daily lives. The initiative seeks to provoke lasting change in society and physical habits in the Bulgarian population. It aims to attract a diverse range of people, regardless of age, gender or social status. Through these good practices, the organization shows its social role in society and employee engagement.

One of the leading organizations in the pharmaceutical sector in Bulgaria - Sopharma AD, uses social engagement as part of its motivational policy. The organization participates in a number of public events, thus motivating its employees to set a good example not only to children but also to adults. An example of such an initiative is "Our PARK (ing) lot is much better than their parking lot". This is a large-scale initiative that is being implemented as part of the parking lots in Sofia are being transformed into public spaces for people. Everyone has the opportunity to participate in the writing of "Life is good when we are healthy" by taking a picture with a letter that you like and become part of the game of the application. As a host \#Healthy usually challenges their visitors to do something good for themselves - to play sports on the spot, to move their thoughts or to hydrate with water or tea.

In its first participation, the social platform "Healthy" of "Sopharma" AD offers measurement of health indicators, advice from medical professionals and the fun "Hugging Machine" - an 


\section{International Journal of Social Science and Economic Research}

ISSN: $2455-8834$

Volume:06, Issue:03 "March 2021"

interactive installation, which after the implementation of the advice gives a gift because we have taken care for ourselves. (https://www.sopharmagroup.com/bg/obshchestvo/healthy-meanshappy)

The support of the company in such initiatives is part of the work to transform the city into a modern and pleasant home for all of us. In this way, the organization motivates employees to live healthy and take care of themselves, thus setting a worthy example to their children. An example of an interesting socially responsible practice on the one hand, and skills for organizational development outside the organization, on the other hand, is the "energy" playground, implemented by "EVN Bulgaria". "Energy" swings convert the energy of movement into electricity in a safe way. This technology allows them to glow with their own light when children swing. They are designed for children from 3 to 12 years. This social practice shows the social responsibility and commitment of the organization, both to nature and to children.

\section{Conclusion}

Whether they are local or not, as well as what field of activity these organizations have, a major factor in their motivational strategies is social policy. They all realize what an impact they would have, not only on the younger generation, but on society as a whole, and so they skillfully use the "power" they have for good deeds. The leaders of these organizations realize that doing good is the best way to set a worthy example for your employees and motivate them to do the same. Subordinates, in turn, will feel this satisfaction, which is irreplaceable and has much greater value than all material things, namely to do something for someone else without demanding something in return.

The management of motivational messages in the modern organization is undoubtedly in a new situation.

The article aims to provoke the attention of the public and public administration on the upcoming challenges related to changes in the management and motivation of human resources, outlining some new ideas on the topic.

As the American writer Stephen King notes: "People's minds are like wells ... deep wells full of fresh water. And sometimes, if a thought is too unpleasant to bear, the person with the thought in question locks it in a heavy box and throws it in his own well. He listens to the rumble and the box disappears ... But even the deepest well has a bottom! And just because something is not in front of your eyes does not mean that it has disappeared. It is still there and lies on the bottom...". So it is with motivating and motivation. 
International Journal of Social Science and Economic Research

ISSN: 2455-8834

Volume:06, Issue:03 "March 2021"

The search for innovative approaches, methods and solutions aimed at finding solutions are probably the "stones in the well" of the current government. This new paradigm of innovation, dynamism and innovation in governance is a challenge that will affect the development of society as a whole in a modern world, resembling a colorful carpet woven of crises, problems and insecurities!

We will end with the words of Yuval Noah Harari: "In a world flooded with unnecessary information, clarity is power. In theory, anyone can get involved in the debate about the future of humanity, but having a clear vision is very difficult. Often we do not even realize that there is a debate or what the main issues are. Billions of us can hardly afford to delve deeper because we have more urgent things to do, to take care of our children or our elderly parents. Unfortunately, history does not make concessions. If the decision for the future of humanity is made in your absence, because you are too busy ensuring your children are fed and clothed - both you and they will be affected by the consequences ". (Harari, 2019)

The age of thoughtful and "smart" decisions has come; the decisions based on complete knowledge of each employee; the decisions that embody the "human face" of the organization and the leadership and the decisions aimed at building attitudes and expectations for a sustainably developing world!

And are we ready for these steps?

Let's try to walk them to understand!

\section{References}

Vasilev, V., Georgiev, K., (2018). Teams and team efficiency. Theoretical navigator and practical manual: Propeller, p. 115-117

Kresnaliyska, G., Chorbadzhiyska, O., Influence of Globalization and Regionalization on Public Administration, NBU, Yearbook of the Department of Administration and Management, Volume 2, 2017, p.24

Vasilev, V., Dimitrova, Sn., „Organizational trust and organizational culture in the public administration“; magazine „Public policies.bg“; Vol 8, № 1; 2017; p.6

Efremovski, I., Vasilev, V., Organizational culture and motivation in public administration - a relation of the future in the public management. KNOWLEDGE : International journal. Vol.4. Skopje : Institute of knowledge management, 2014. pp. 102-106, 2014. 


\section{International Journal of Social Science and Economic Research}

ISSN: $2455-8834$

Volume:06, Issue:03 "March 2021"

Vasilev, V., Stefanova, D., Angelova, S., (2017). Effective communications in public management : Propeller, p.59

Vasilev, V., Efremovski, I., (2017). Organizational culture and motivation of staff - theoretical foundations and good practices: Propeller, p. 180

Vasilev, V., Icheva, M., The COVID-19 Crisis and Lessons from Leadership, Social Responsibility and Effective Communication "; "Central Russian Bulletin of Social Sciences"; Central Russian Journal of Social Sciences 15 (6): 217-227; Volume 15 No. 6; ISSN (Print): 2071-2367, ISSN (Online): 2500-2090 .; DOI: 10.22394 / 2071-2367-2020-15-6-217-227; Oryol, Oryol region, Russian Federation; pg. 217-227; $/ 2020 \quad$ г.; https://orel.ranepa.ru/nauka/srednerusskiy-vestnik-obshchestvennykh-nauk/tekushchiynomer.php?s=29976; https://www.elibrary.ru/item.asp?id=44460110

Gigauri; Iza; Implications of COVID-19 for Human Resource; Management SSRG International Journal of Economics and Management Studies; Volume 7 Issue 11, p. 26, November, 2020

The Strategy for Development of the State Administration 2014-2020, adopted by Decision № 140 of the Council of Ministers of 17.03.2014. Available at http://www.strategy.bg/StrategicDocuments/View.aspx?lang=bg-BG\&Id=891

The Handbook on Crowdsourcing and Civic Hacking, Available at http://www.strategy.bg/Publications/View.aspx?lang=bg-BG\&categoryId=\&Id=287

Engagement Barometer, Institute of Public Administration, Available at https://www.ipa.government.bg/sites/default/files/barometer analysis 2020 0.pdf

Vasilev, V., Belyovksa, Tsv., (2018). Organizational behavior. Theoretical foundations: Propeler, p. 23

Vasilev, V., Ognyanski, D., "The New Face of Public Management - About The "Smart City" and its Impact on The Future Development of Society“; KNOWLEDGE International Journal; Vol. 42 №1 (2020); „The Power of Knowledge“; Institute of Knowledge Management; Skopje; ISSN:1857-923X (Printed); ISSN: 2545-4439 (Online); 2020; p. 91-92; https://ikm.mk/ojs/index.php/KIJ/article/view/4515

Nopdstom, K. , Ridderstrale,J., (1999). Talent Makes Capital Dance : BookHouse Publishing, p. 210-211

https://what-europe-does-for-me.eu/bg/portal/2/B02 
International Journal of Social Science and Economic Research

ISSN: 2455-8834

Volume:06, Issue:03 "March 2021"

https://m.president.bg/bg/static2/Balgarskata-koleda

http://www.blgmun.com/?show=news\&nid=4816

https://daizchistim.bg/za-kampaniqta

https://csr.bg

https://bg.coca-colahellenic.com

https://www.sopharmagroup.com/bg/obshchestvo/healthy-means-happy

https://old.evn.bg/Medii/20141014Detska_ploshtadka.aspx?listnode=/Medii/Arhiv

Harari, N. (2019). 21 lessons for 21st Century: East West, p. 4 